\title{
Effects of highly active antiretroviral treatment on liver and renal functions of HIV-infected patients attending the day care clinic of the Bamenda Regional Hospital, Cameroon
}

\author{
${ }^{* 1}$ Samje, M., ${ }^{2}$ Youego, E. K. J., ${ }^{2}$ Kefeyin, T. W., and ${ }^{3}$ Lukong, H. \\ ${ }^{1}$ Department of Biomedical Sciences, Faculty of Health Sciences, University of Bamenda, \\ P. O. Box 39, Bambili, Republic of Cameroon \\ ${ }^{2}$ Department Medical Laboratory Sciences, University of Bamenda, Cameroon \\ ${ }^{3}$ Department of Medical Laboratory Sciences, Kesmonds International University, Cameroon \\ *Correspondence to: msamje@gmail.com; +237677679112
}

\begin{abstract}
:
Background: Though the development of antiretroviral therapy has brought some relief to the menace of HIV infections, the side effects and toxicity of these drugs can still present a major challenge to users, thus leading to a switch or discontinuation of treatment. The aim of this study was to determine the effect of antiretroviral treatment on some biochemical markers of liver and renal functions among HIV-infected patients receiving treatment at the Day Care Clinic of the Regional Hospital, Bamenda, Cameroon.

Methodology: A case control study design comprising $100 \mathrm{HIV}$-infected patients on highly active antiretroviral therapy (HAART) and 100 HIV-negative controls was conducted from February to May 2019. The serum activity of aspartate amino transferase (AST) and alanine amino transferase (ALT), and serum creatinine levels for each group were measured using BIOSMART 240 autoanalyzer. The estimated glomerular filtration rate (eGFR) was calculated using the Cockcroft-Gault formula while proteinuria was determined with the CYBOW 11M strips. Data were analyzed using IBM SPSS version 21.0. Differences in the serum activity and levels of the biomarkers between the case and control groups were analyzed using the Chi-square test.

Results: The prevalence of transaminitis (AST and ALT >40.0 U/L) among HAART-treated participants was $26.0 \%$ for AST and $20 \%$ for ALT while that of HIV-negative controls were $15 \%$ and $12 \%$ respectively but the difference was not statistically significant $(p>0.05)$. Elevated serum creatinine level $(>1.4 \mathrm{mg} / \mathrm{dL}$ ) was seen in $25 \%$ of HAART-treated group compared to $7 \%$ in HIV-negative control $(p=0.0010)$ while renal impairment $\left(e G F R<60 \mathrm{ml} / \mathrm{min} / 1.73 \mathrm{~m}^{2}\right)$ was seen in $24 \%$ of HAART-treated and $14 \%$ of HIV-negative group $(p=0.1048)$. Elevated activity of transaminases and levels of creatinine, proteinuria and abnormal eGFR in HAART-treated patients were mostly seen in those who were on first line antiretroviral therapy, and those who have been on treatment for over 5 years.

Conclusion: HAART is associated with transaminitis and elevated serum creatinine but no increase in renal impairment compared to the general population. It is important that following initiation of HAART, liver and kidney functions are regularly monitored.
\end{abstract}

Keywords: HIV; HAART; AST; ALT; eGFR

Received September 16, 2019; Revised April 23, 2020; Accepted April 26, 2020

Copyright 2020 AJCEM Open Access. This article is licensed and distributed under the terms of the Creative Commons Attrition 4.0 International License <a rel="license" href="http://creativecommons.org/licenses/by/4.0/", which permits unrestricted use, distribution and reproduction in any medium, provided credit is given to the original author(s) and the source.

\section{Effets du traitement antirétroviral fortement actif sur les fonctions hépatiques et rénales chez des patients infectés par le VIH assistant au centre de traitement de I'hôpital régional de Bamenda, Cameroun}

\author{
${ }^{* 1}$ Samje, M., ${ }^{2}$ Youego, E. K. J., ${ }^{2}$ Kefeyin, T. W., et ${ }^{3}$ Lukong, H. \\ ${ }^{1}$ Département des sciences biomédicales, Faculté des sciences de la santé, Université de Bamenda, \\ P. O. Box 39, Bambili, République du Cameroun
}




\author{
${ }^{2}$ Département des sciences de laboratoire médical, Université de Bamenda, Cameroun \\ ${ }^{3}$ Département des sciences de laboratoire médical, Université internationale de Kesmonds, Cameroun \\ *Correspondance à: msamje@gmail.com; +237677679112
}

\title{
Resumé:
}

Contexte: Bien que le développement de la thérapie antirétrovirale ait apporté uncertain soulagement à la menace par l'infection au VIH, les effets secondaires et les toxicités de ces médicaments peuvent encore représenter un défi majeur pour les utilisateurs conduisant ainsi à un changement ou à l'arrêt du traitement. Le but de cette étude était de déterminer l'effet du traitement antirétroviral sur certains marqueurs biochimiques de la fonction hépatique et rénale chez les patients infectés par le VIH recevant un traitement au Centre de traitement antirétrovirale de l'hôpital régional de Bamenda, au Cameroun.

Méthodologie: Un modèle d'étude cas-témoins comprenant 100 patients infectés par le VIH sous traitement antirétroviral hautement actif (TAHA) et 100 témoins séronégatifs a été mené de février à mai 2019. L'activité sérique de l'aspartate amino transférase (ASAT) et de l'alanine amino transférase (ALAT) et les niveaux de créatinine sérique pour chaque groupe ont été mesurés en utilisant l'autoanalyseur BIOSMART 240. Le débit de filtration glomérulaire estimé (DFGe) a été calculé en utilisant la formule Cockcroft-Gault tandis que la protéinurie a été déterminée avec les bandelettes CYBOW 11M. Les données ont été analysées à l'aide d'IBM SPSS version 21.0. Les différences dans l'activité sérique et les niveaux des biomarqueurs entre le groupe de cas et le groupe témoin ont été analysées à l'aide du test du chi carré.

Résultats: La prévalence de la transaminite (ASAT et ALAT> 40,0 U/L) chez les participants traités par TAHA était de $26,0 \%$ pour I'ASAT et $20 \%$ pour I'ALAT tandis que celle des témoins séronégatifs était respectivement de $15 \%$ et $12 \%$ mais la différence n'était pas statistiquement significatif $(p>0,05)$. Un taux de créatinine sérique élevé $(>1,4$ $\mathrm{mg} / \mathrm{dL}$ ) a été observé chez $25 \%$ des patients traités par TAHA, contre $7 \%$ chez les témoins séronégatifs $(p=0,0010)$, tandis qu'une insuffisance rénale (DFGe $<60 \mathrm{ml} / \mathrm{min} / 1,73 \mathrm{~m}^{2}$ ) était vu dans $24 \%$ des patients traités par TAHA et $14 \%$ des patients séronégatifs pour le VIH $(p=0,1048)$. Une activité élevée des transaminases et des niveaux de créatinine, de protéinurie et de DFGe anormal chez les patients traités par TAHA ont été principalement observés chez ceux qui étaient sous traitement antirétroviral de première ligne et ceux qui suivaient un traitement depuis plus de 5 ans.

Conclusion: la multithérapie est associée à une transaminite et à une élévation de la créatinine sérique mais pas d'augmentation de l'insuffisance rénale par rapport à la population générale. Il est important qu'après l'initiation de la multithérapie, les fonctions hépatiques et rénales soient régulièrement surveillées.

Mots-clés: VIH; TAHA; ASAT; ALAT; eGFR

\section{Introduction:}

Human immunodeficiency virus (HIV) leads to a depletion in $\mathrm{CD}_{4}{ }^{+}$cells thus fueling opportunistic infections and consequently reducing life expectancy (1). The HIV/AIDS pandemic is estimated to have killed more than 25 million people worldwide (2). The management of this disease normally includes the use of simple antiretroviral drugs. Several classes of antiretroviral agents acting on different stages of the HIV life cycle have been reported. Highly active antiretroviral therapy (HAART), multiple drugs with different viral targets have been shown to decrease total burden of HIV in infected patients and maintain the function of the immune system (3). The arrival of HAART has greatly enhanced long-term viral suppression, decrease opportunistic infections and increased quality of life (QoL) in HIV-infected population worldwide (4).

While the liver is known as the gate way of drugs to the body, the kidney serves as an exit of the metabolized substance from the body. The toxicity of HAART, especially on the liver and kidneys, has emerged as an important complication and eventually a major reason for antiretroviral therapy shift and/or discontinua- tion of the offending drug (5). The use of antiretrovirals have been associated with liver disease. Although many sites in the body such as the gut, lungs and kidneys are involved in drug metabolism, the liver is the most metabolically active tissue and is known to be responsible for the majority of drug metabolism. It is hypothesized that following exposure to the drug, the toxic moiety induces some type of stress or functional disturbance, with mitochondrial injury being one of the most important targets recognized $(6,7)$. The mechanisms for drug-induced liver injury also include dosedependent toxicity, hypersensitivity reactions, and immune reconstitution (8).

The association between HIV infection and renal disease was first reported as far back as 1984 by researchers in New York and Miami $(9,10)$. Renal disease in HIV can result from the use of HAART with their associated adverse effects (11) that may shorten the lifespan of patients. Several routes for drug elimination from the body exist with most drugs eliminated by pathways that involve kidneys or liver. Renal excretion plays an important role in eliminating unchanged drugs or their metabolites into urine. The diagnosis of HAART induced adverse effects on the kidney involves performing renal 
function tests, a group of clinical biochemistry laboratory blood tests designed to give information about the state of a patients' kidney.

Considering the important role of the liver and kidney in respectively metabolizing or detoxifying drugs and excreting waste products of metabolism, these vital organs need to be monitored during therapies of different drug combinations and regimens in order to be sure that harm is not done to them. This study was therefore aimed at evaluating the effects of different HAART regimens on the liver and kidney functions of patients undergoing such treatment at the Bamenda Regional Hospital, Cameroon.

\section{Materials and methods:}

\section{Study area}

The study was carried out at the Day Care Clinic of the Bamenda Regional Hospital, Cameroon. The Bamenda Regional Hospital is in the metropolitan city of Bamenda with a population of over 650,000 inhabitants. It is the major Government hospital in the northwest region of Cameroon and serve as a referral hospital in this region.

\section{Study design}

A case-control study design was employed where the case group comprised HIVinfected subjects on HAART while the control group comprised HIV-negative individuals. The markers of liver and kidney functions were assessed and compared between the groups.

\section{Subjects and selection criteria}

The subjects were HIV-infected patients on HAART (case) and HIV negative individuals (control). The sample size for the study was determined using the Cochran's formula (12) with an estimated prevalence obtained from a study carried out by Wondifraw and others (13). The sample size of 200 was obtained; 100 subjects for the case group and 100 for the control group. Inclusion criteria for cases were; HIV-infection in patient within the age group 2065 years on HAART with no underlying hypertension, diabetes, kidney diseases; not pregnant; not on any medication (except HAART); and negative for hepatitis $B$ or $C$ virus infection. The controls were apparently healthy subjects.

The Determine ${ }^{\circledR} \mathrm{HIV}-1 / 2 \mathrm{Ag} / \mathrm{Ab}$ Combo (Alere Medical Co., Ltd, Matsuhidai, MatsudoShi, China) was used as first line HIV screening test while reactive samples were confirmed by the OraQuick (OraSure Technologies, Inc, Bethlehem) in line with national algorithm for HIV diagnosis in Cameroon.

\section{Ethical approval}

Ethical clearance for the study was obtained from the University of Bamenda Institutional Review Board while administrative authorization was obtained from the Director of the Hospital. Signed informed consent was equally obtained from the study subjects.

\section{Data collection}

A structured questionnaire was used to collect socio-demographic information. For patients who could not read or write, information was collected orally and then transcribed. Treatment details including types of drugs, duration of treatment together with other clinical parameters were obtained from the medical records of the subjects.

\section{Specimen collection}

From each subject participant, approximately $4 \mathrm{ml}$ of venous blood was collected into a labelled dry specimen tube and $10 \mathrm{ml}$ of urine into sterile urine sample bottle. The blood was allowed to clot and then centrifuged at $3000 \mathrm{rpm}$ for 5 minutes to obtain serum for the measurement of serum activity of liver enzymes (AST and $A L T$ ) and serum creatinine level. Renal function was assessed by serum creatinine level and creatinine clearance by estimating the glomerular filtration rate (eGFR).

\section{Measurement of ALT and AST activity}

Serum activity of ALT and AST was measured using the BIOSMART 240 analyzer (BIONLINE-S.R.L). Samples were loaded in the tray of the analyzer and aliquot dispensed into the reaction vessel together with the reagents. After the solution was mixed, it passed through an in-built colorimeter which measured the absorbance and displayed the concentration of the analyte. Calibration was done before running each set of samples using reagents and quality control samples that was provided in the test kit (REF 92027 AST/GOT-ALT/GPT). The analyzer calculated and expressed ALT and AST activity in $\mathrm{U} / \mathrm{L}$ in the reaction at $37^{\circ} \mathrm{C}$ within three minutes.

Interpretation of serum activity of the aminotransferases was based on the AIDS Clinical Trial Group grading system with ALT and AST elevations $>40.0 \mathrm{U} / \mathrm{L}$, which for adults, is the upper limit of normal (ULN) range in individuals with normal ALT and AST values at baseline. Hepatotoxicity grades were categorized as Grade 1 when ALT and AST values lie between 1.25 and $<2.5 \times$ ULN; Grade 2 when values lie between 2.5 and $<5.0 \times$ ULN; Grade 3 when values lie between 5.0 and $<10 \times$ ULN; and Grade 4 when values are $\geq 10 \times$ ULN (14). 


\section{Measurement of creatinine}

Serum creatinine level was measured automatically using the BIOSMART 240 analyzer as described for AST and ALT, except for the reagents and control samples. The results were compared with the normal range for creatinine (0.6-1.4 mg/dL).

\section{Detection of urine protein}

Protein was detected in urine qualitatively using the CYBOW $11 \mathrm{M}$ strips. Briefly, the tip of test strip was dipped into urine for a maximum of 5 seconds and deviation in normal color was evaluated visually with the aid of a color chart labelled on the strip container.

\section{Creatinine clearance $(\mathrm{Ccr})$ estimation}

The estimated Glomerular Filtration Rate (eGFR) was calculated using the CockcroftGault formula; GFR $=\frac{(140-\text { age }) \times \text { weight }}{72 \mathrm{Scr}}(\times 0.85$ if female $)$, which took into consideration serum creatinine (Scr), age, sex and weight of participant (15). The National Kidney Foundation clinical practice guideline was used to classify renal impairment based on the estimated GFR values. The eGFR values of $\geq 90 \mathrm{ml} / \mathrm{min} / 1.73 \mathrm{~m}^{2}, 60-89 \mathrm{ml} / \mathrm{min} /$ $1.73 \mathrm{~m}^{2}, 30-59 \mathrm{ml} / \mathrm{min} / 1.73 \mathrm{~m}^{2}, 15-29 \mathrm{ml} / \mathrm{min} /$ $1.73 \mathrm{~m}^{2}$ and $<15 \mathrm{ml} / \mathrm{min} / 1.73 \mathrm{~m}^{2}$ was interpreted as normal, mild, moderate, severe and kidney failure respectively. Renal function impairment in this study was defined as eGFR $<60 \mathrm{ml} / \mathrm{min} /$ $1.73 \mathrm{~m}^{2}(21)$.

\section{Statistical analysis}

Data were analyzed using the Statistical Package for the Social Sciences (SPSS) version 20 software program. Descriptive statistics, Chisquare test and Pearson's product were used to test the significance of the results at $95 \%$ confidence interval.

\section{Results:}

Of the 200 participants recruited in the study, 100 were HIV-infected patients on HAART (case) while 100 were HIV negative (control) subjects. There were 18 males and 82 females in the case group ( $\mathrm{M}: \mathrm{F}$ ratio of $1: 4.5)$ while there were 46 males and 54 females in the control group (M: F ratio of $1: 1.2$ ).

Majority of the case subjects were in the age group $36-50$ years (55\%) while for the control, majority (58\%) were in the $20-35$ years age group. Most of the HIV-infected patients $(55 \%)$ were on the TDF+3TC+EFV HAART regimen and $36 \%$ had been on therapy for duration of 5-10 years (Table 1 ).

Table 1: Demographic and clinical characteristics of the study population

\begin{tabular}{|c|c|c|c|}
\hline \multicolumn{2}{|c|}{ Characteristics } & \multirow{2}{*}{$\begin{array}{c}\text { HAART treated group (\%) } \\
(\mathrm{n}=100)\end{array}$} & \multirow{2}{*}{$\begin{array}{c}\text { HIV negative control (\%) } \\
(\mathrm{n}=100)\end{array}$} \\
\hline Gender & Male & & \\
\hline \multirow{4}{*}{ Age group (years) } & Female & $82(82)$ & $54(54)$ \\
\hline & $20-35$ & $14(14)$ & $58(58)$ \\
\hline & $36-50$ & $55(55)$ & $22(22)$ \\
\hline & $51-65$ & $31(31)$ & $20(20)$ \\
\hline \multirow{3}{*}{$\begin{array}{l}1^{\text {st }} \text { line ARV } \\
\text { therapy }\end{array}$} & $\mathrm{TDF}+3 \mathrm{TC}+\mathrm{EFV}$ & $55(55)$ & NA \\
\hline & $\mathrm{AZT} / 3 \mathrm{TC}+\mathrm{EFV}$ & $3(3)$ & NA \\
\hline & $\mathrm{AZT} / 3 \mathrm{TC} / \mathrm{NVP}$ & $11(11)$ & NA \\
\hline \multirow{2}{*}{$\begin{array}{l}\text { 2nd line ARV } \\
\text { therapy }\end{array}$} & $A Z T+3 T C+A T Z / r$ & $6(6)$ & NA \\
\hline & $\mathrm{TDF} / 3 \mathrm{TC}+\mathrm{ATV} / \mathrm{r}$ & $11(11)$ & NA \\
\hline \multirow{3}{*}{$\begin{array}{l}\text { Duration of } \\
\text { therapy }\end{array}$} & $\leq 4$ years & $29(29)$ & NA \\
\hline & $5-10$ years & $36(36)$ & NA \\
\hline & $>10$ years & $35(35)$ & NA \\
\hline
\end{tabular}


Table 2a: Elevated transaminase activity in HIV-infected HAART treated and HIV-negative subjects

\begin{tabular}{|c|c|c|c|c|c|c|}
\hline Patient status & $\begin{array}{l}\text { Number (\%) with elevated } \\
\text { AST activity }(>40 \mathrm{U} / \mathrm{L})\end{array}$ & $\mathrm{X}^{2}$ & $p$ value & $\begin{array}{l}\text { Number }(\%) \text { with elevated } \\
\text { ALT activity }(>40 \mathrm{U} / \mathrm{L})\end{array}$ & $\mathrm{X}^{2}$ & $p$ value \\
\hline $\begin{array}{l}\text { HAART treated } \\
\quad(n=100)\end{array}$ & $26(26)$ & 3.068 & $0.0798^{\mathrm{ns}}$ & $20(20)$ & 1.823 & $0.1170^{\text {ns }}$ \\
\hline $\begin{array}{l}\text { HIV negative } \\
\quad(n=100)\end{array}$ & $15(15)$ & & & $12(12)$ & & \\
\hline Total $(n=200)$ & $41(20.5)$ & & & $32(16)$ & & \\
\hline
\end{tabular}

Table 2b: Elevated transaminase activity in HIV-infected HAART treated and HIV-negative participants relative to gender

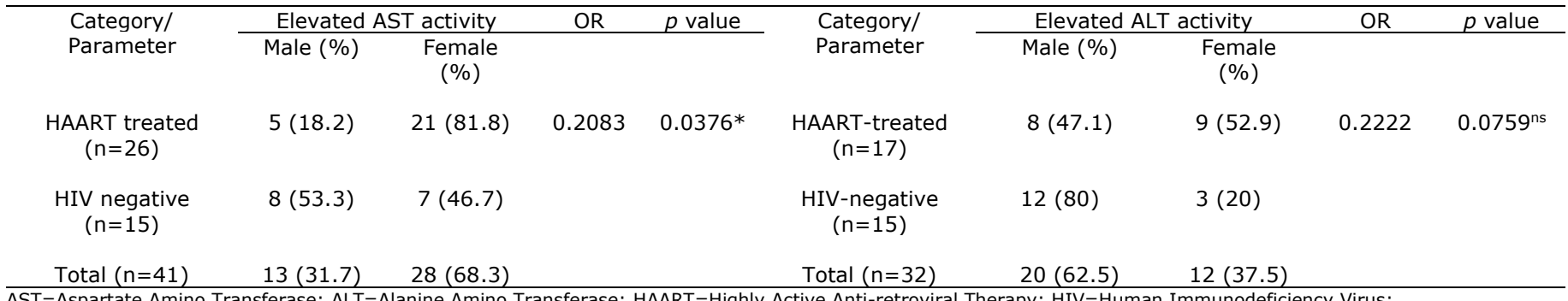

AST=Aspartate Amino Transferase; ALT=Alanine Amino Transferase; HAART=Highly Active Anti-retroviral Therapy; HIV=Human Immunodeficiency Virus; $*=$ significant difference; $\mathrm{ns}=$ no significant difference; $\mathrm{OR}=$ Odds Ratio

Table 2c: Elevated transaminase activity in HIV-infected HAART treated and HIV-negative participants relative to age group

\begin{tabular}{|c|c|c|c|c|c|c|c|c|c|c|}
\hline \multirow{2}{*}{$\begin{array}{c}\text { Category/parameter/ } \\
\text { age group (years) }\end{array}$} & \multicolumn{3}{|c|}{${ }^{+}$Elevated AST activity } & \multirow{2}{*}{$\frac{\mathrm{X}^{2}}{1.040}$} & \multirow{2}{*}{$\frac{p \text { value }}{0.5944^{\text {ns }}}$} & \multicolumn{3}{|c|}{${ }^{++}$Elevated ALT activity } & \multirow{2}{*}{$\frac{X^{2}}{7.003}$} & \multirow{2}{*}{$\frac{p \text { value }}{0.0301^{*}}$} \\
\hline & $\begin{array}{c}20-35 \\
(\%)\end{array}$ & $\begin{array}{c}36-50 \\
(\%)\end{array}$ & $\begin{array}{c}51-65 \\
(\%)\end{array}$ & & & $\begin{array}{c}20-35 \\
(\%)\end{array}$ & $\begin{array}{c}36-50 \\
(\%)\end{array}$ & $\begin{array}{c}51-65 \\
(\%)\end{array}$ & & \\
\hline HAART treated & $\begin{array}{c}6 \\
(23.1)\end{array}$ & $\begin{array}{c}11 \\
(42.3)\end{array}$ & $\begin{array}{c}9 \\
(34.6)\end{array}$ & & & $\begin{array}{c}9 \\
(45)\end{array}$ & $\begin{array}{c}7 \\
(35)\end{array}$ & $\begin{array}{c}4 \\
(20)\end{array}$ & & \\
\hline HIV negative & $\begin{array}{c}4 \\
(26.7)\end{array}$ & $\begin{array}{c}4 \\
(26.7)\end{array}$ & $\begin{array}{c}7 \\
(46.7)\end{array}$ & & & $\begin{array}{c}2 \\
(16.7)\end{array}$ & $\begin{array}{c}2 \\
(16.7)\end{array}$ & $\begin{array}{c}8 \\
(66.6)\end{array}$ & & \\
\hline Total & $\begin{array}{c}10 \\
(24.4)\end{array}$ & $\begin{array}{c}15 \\
(36.6)\end{array}$ & $\begin{array}{c}16 \\
(39.0)\end{array}$ & & & $\begin{array}{c}11 \\
(34.4)\end{array}$ & $\begin{array}{c}9 \\
(28.1)\end{array}$ & $\begin{array}{c}12 \\
(37.5)\end{array}$ & & \\
\hline
\end{tabular}
AST = Aspartate Amino Transferase; ALT = Alanine Amino Transferase; HAART = Highly Active Anti-retroviral Therapy; HIV = Human Immunodeficiency
elevated AST activity is $41 ;++=$ no of patients with elevated ALT activity is $32 ; \mathrm{X}^{2}=$ Chi square; ${ }^{*}=$ significant difference; ns $=$ no significant difference;

As shown in Table $2 a, 26 \%$ of the 100 HAART-treated HIV-infected patients had elevated serum AST activity (>40 U/L) which was not significantly different from $15 \%$ of 100 HIV-negative control $(p=0.0798)$. Similarly, $20 \%$ of the 100 HAART-treated HIV-infected patients had elevated serum ALT activity that was also not significantly different from $12 \%$ of 100 HIV-negative control $(p=0.1770)$. The elevated AST activity with respect to gender in the HAART treated patients was significantly different from the HIV-negative control, with more females $(81.8 \%)$ than males $(18.2 \%)$ having elevated values in the HAART-treated group $(p=0.0376)$ as distinct from $46.7 \%$ for females and $53.3 \%$ for males in the HIV- negative control (Table 2b). However, for elevated ALT activity, there was no significant differrence with respect to gender between HAARTtreated and HIV-negative patients $(p=0.0759)$.

With respect to age group as shown in Table 2c, there was statistically significant difference $(p=0.0301)$ in the elevated ALT activity between HAART-treated and HIVnegative patients, with those in age group 2035 years more affected $(45 \%)$ in the HAARTtreated group and those in age group 51-65 years more affected in HIV-negative group $(66.6 \%)$. However, there was no significant difference in the elevated AST activity with respect to age group in both category of patients $(p=0.5944)$. 
Table 3a: Elevated serum creatinine, proteinuria and abnormal eGFR in HAART treated and HIV negative subjects

\begin{tabular}{|c|c|c|c|c|c|c|c|c|c|}
\hline Patient status & $\begin{array}{l}\text { Number (\%) with } \\
\text { elevated creatinine }\end{array}$ & $\mathrm{X}^{2}$ & $p$ value & $\begin{array}{c}\text { Number (\%) } \\
\text { with proteinuria }\end{array}$ & $\mathrm{X}^{2}$ & $p$ value & $\begin{array}{c}\text { Number (\%) with } \\
\text { eGFR }<60 \mathrm{ml} / \mathrm{min} / 1.73 \mathrm{~m}^{2}\end{array}$ & $\mathrm{X}^{2}$ & $p$ value \\
\hline $\begin{array}{l}\text { HAART treated } \\
\quad(n=100)\end{array}$ & $25(25)$ & 10.751 & $0.001 *$ & $5(5)$ & 0.7659 & $0.0886^{\mathrm{ns}}$ & $24(24)$ & 2.632 & $0.1048^{\text {ns }}$ \\
\hline $\begin{array}{l}\text { HIV negative } \\
\quad(n=100)\end{array}$ & $7(7)$ & & & $7(7)$ & & & $14(14)$ & & \\
\hline Total $(n=200)$ & $32(16)$ & & & $12(6)$ & & & $38(19)$ & & \\
\hline
\end{tabular}
Virus; *statistically significant; ns = not significant

Table 3b: Classification of renal status based on eGFR among the HAART -treated patients by gender and age group

\begin{tabular}{|c|c|c|c|c|c|c|c|c|c|}
\hline \multirow[t]{2}{*}{ Renal status } & \multicolumn{3}{|c|}{ Gender } & \multirow[t]{2}{*}{$p$ value* } & \multicolumn{4}{|c|}{ Age group (years) } & \multirow[t]{2}{*}{$p$ value* } \\
\hline & Male (\%) & Female (\%) & Total & & $20-35(\%)$ & $36-50(\%)$ & $51-65(\%)$ & Total & \\
\hline Normal & 7 (38.9) & 13 15.9) & 20 & $0.5502^{\mathrm{ns}}$ & $6(42.9)$ & $10(18.2)$ & $4(12.9)$ & 20 & $0.1783^{\text {ns }}$ \\
\hline Mild impairment & $8(44.4)$ & $48(58.5)$ & 56 & & $6(42.9)$ & $34(61.8)$ & $16(51.6)$ & 56 & \\
\hline $\begin{array}{c}\text { Moderate } \\
\text { impairment }\end{array}$ & $3(16.7)$ & $21(25.6)$ & 24 & & $2(14.2)$ & $11(20)$ & $11(35.5)$ & 24 & \\
\hline $\begin{array}{c}\text { Severe } \\
\text { impairment }\end{array}$ & 0 & 0 & 0 & & 0 & 0 & 0 & 0 & \\
\hline Kidney failure & 0 & 0 & 0 & & 0 & 0 & 0 & 0 & \\
\hline Total & 18 & 82 & 100 & & 14 & 55 & 31 & 100 & \\
\hline
\end{tabular}

Table 3c: Classification of renal impairment based on eGFR among the HIV-negative patients by gender and age group

\begin{tabular}{|c|c|c|c|c|c|c|c|c|c|}
\hline \multirow[t]{2}{*}{ Renal status } & \multicolumn{3}{|c|}{ Gender } & \multirow[t]{2}{*}{$p$ value* } & \multicolumn{4}{|c|}{ Age group (years) } & \multirow[t]{2}{*}{$p$ value* } \\
\hline & Male (\%) & Female (\%) & Total & & $20-35(\%)$ & $36-50(\%)$ & $51-65(\%)$ & Total & \\
\hline Normal & $18(39.1)$ & $18(33.3)$ & 36 & $0.1591^{\mathrm{ns}}$ & $25(43.1)$ & $6(27.3)$ & $5(25)$ & 36 & $0.0103^{s}$ \\
\hline Mild impairment & $19(41.3)$ & $31(57.4)$ & 50 & & $28(48.3)$ & $14(63.6)$ & $8(40)$ & 50 & \\
\hline $\begin{array}{c}\text { Moderate } \\
\text { impairment }\end{array}$ & $7(15.2)$ & $5(9.3)$ & 12 & & $5(8.6)$ & $2(9.1)$ & $5(25)$ & 12 & \\
\hline $\begin{array}{c}\text { Severe } \\
\text { impairment }\end{array}$ & $1(2.2)$ & 0 & 1 & & 0 & 0 & $1(5)$ & 1 & \\
\hline Kidney failure & $1(2.2)$ & 0 & 1 & & 0 & 0 & $1(5)$ & 1 & \\
\hline Total & 46 & 54 & 100 & & 58 & 22 & 20 & 100 & \\
\hline
\end{tabular}

Table 3a shows the number of subjects (case and control) with elevated serum creatinine level, proteinuria and abnormal eGFR $\left(<60 \mathrm{ml} / \mathrm{min} / 1.73 \mathrm{~m}^{2}\right)$. Serum creatinine was elevated in $25 \%$ of patients in the HAART-treated group, which was significantly higher than $7 \%$ in the HIV negative group $(p=0.0010)$. The eGFR was abnormal $\left(<60 \mathrm{ml} / \mathrm{min} / 1.73 \mathrm{~m}^{2}\right)$ in $24 \%$ of patients in the HAART-treated group, but this was not significantly higher than $14 \%$ in the HIV-negative group $(p=0.1048)$. Similarly, the prevalence of $5 \%$ for proteinuria in HAARTtreated group was not significantly different from $7 \%$ in the HIV-negative control group $(p=0.08865)$.
Tables $3 \mathrm{~b}$ and $3 \mathrm{c}$ show the classification of renal impairment in relation to gender and age group in both HAART-treated and HIVnegative patients. In the HAART-treated group, renal impairment (eGFR $<60 \mathrm{ml} / \mathrm{min} / 1.73 \mathrm{~m}^{2}$ ) was higher in females $(25.6 \%)$, but this was not significantly different $(p=0.5502)$ from males $(16.7 \%)$, and also there was no significant difference with respect to age group (Table $3 b$ ). In the HIV-negative group, there was no significant difference $(p=0.1591)$ in the occurrence of renal impairment (eGFR $<60 \mathrm{ml} / \mathrm{min} / 1.73 \mathrm{~m}^{2}$ ) between males (19.6\%) and females (9.3\%) but the occurrence was significantly higher ( $p=$ 0.0103 ) in age group 51-65 years (Table $3 c$ ). 


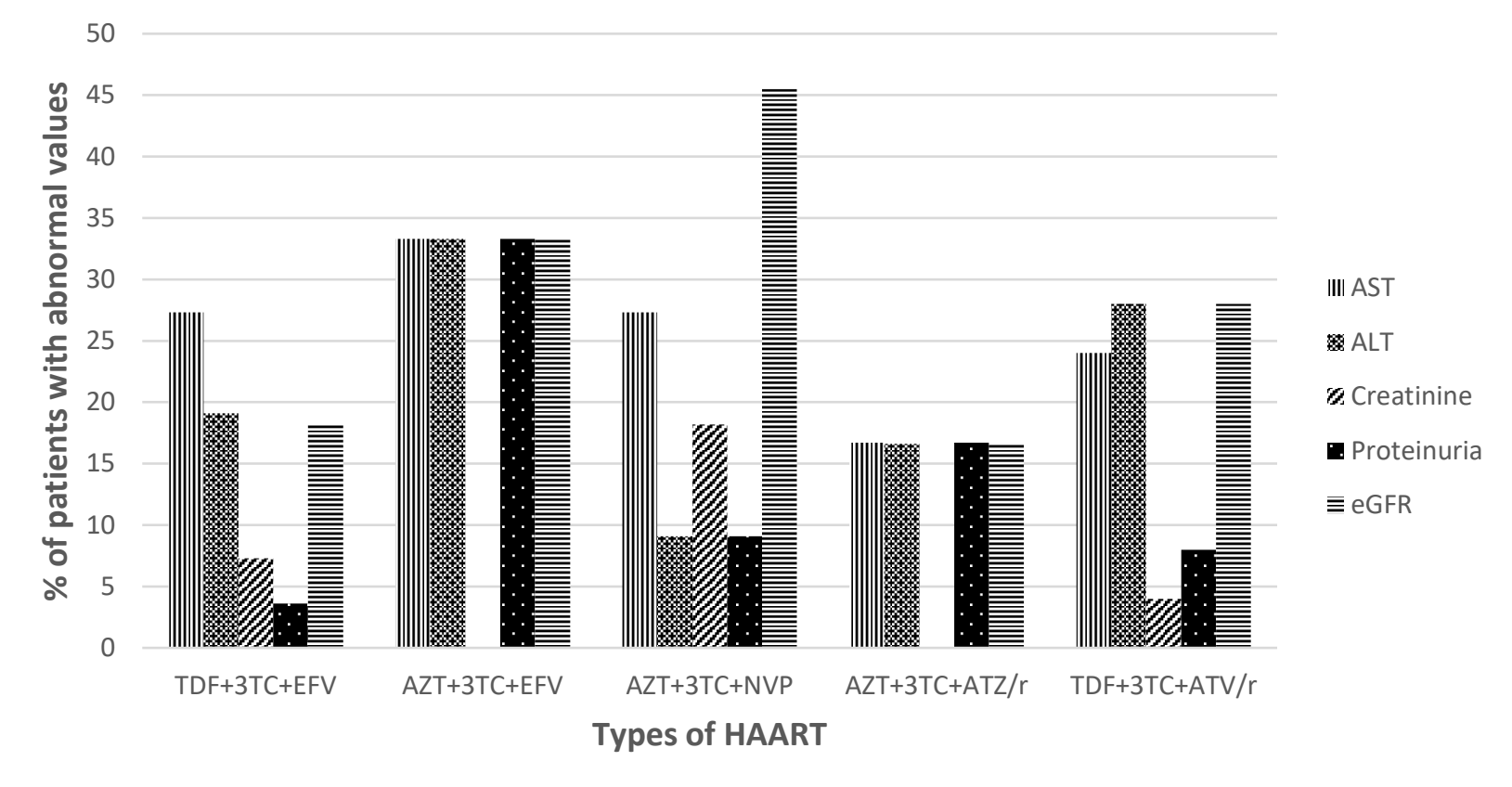

Fig 1: Effect of different types of HAART treatment on markers of liver and kidney function

$\mathrm{AST}=$ Aspartate Transaminase; ALT $=$ Alanine Transaminase $; \mathrm{TDF}+3 \mathrm{TC}+\mathrm{EFV}=$ Tenofovir + Lamivudine+ Efavirenz; AZT $/ 3 \mathrm{TC}+\mathrm{EFV}=$ Zidovudine+ Lamivudine+ Efavirenz; AZT/3TC/NVP = Zidovudine+ Lamivudine+ Nevirapine; AZT+3TC+ATZ/r = atazanavir/ritonavir; TDF/3TC+ATV/r = Tenofovir+ Lamivudine+ atazanavir/ritonavir; eGFR = estimated Glomerular Filtration Rate;

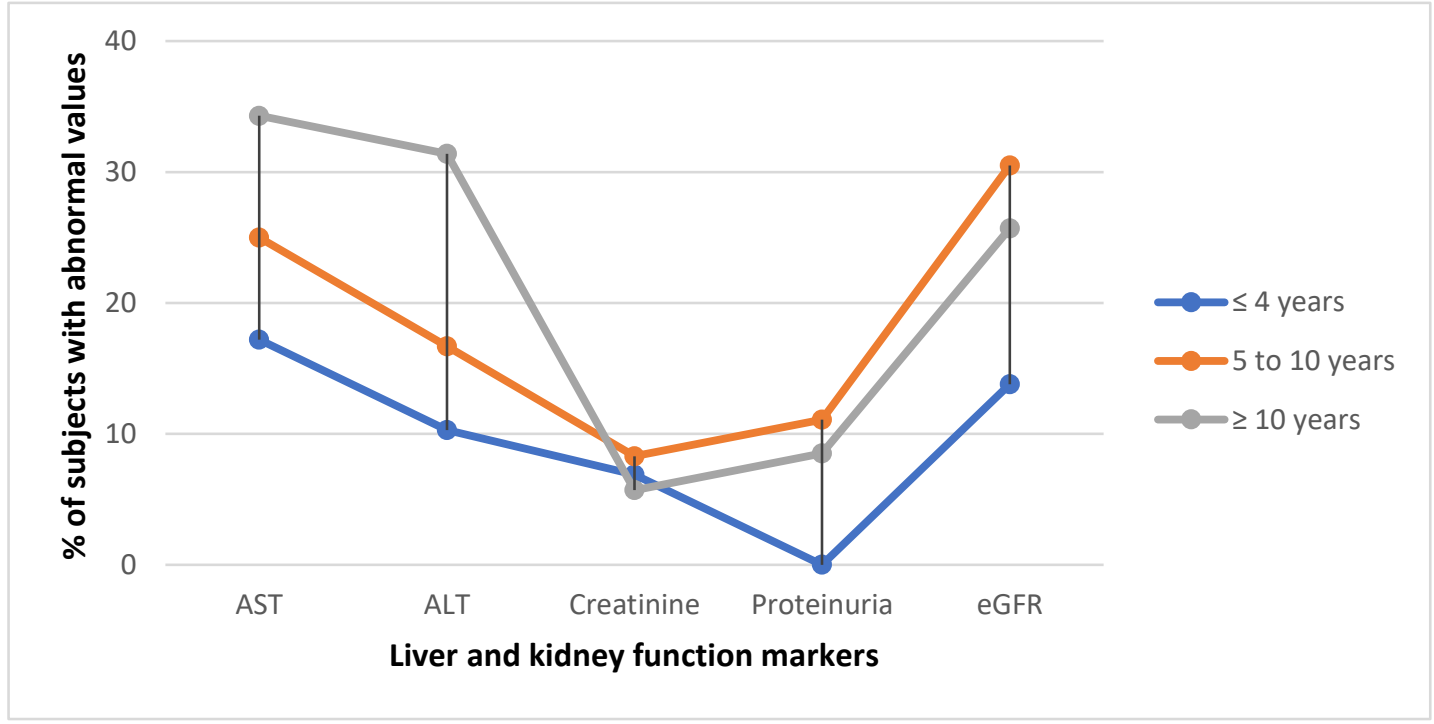

Fig 2: Levels of markers of liver and kidney function and duration of treatment

AST = Aspartate Transaminase; ALT = Alanine Transaminase; eGFR = estimated Glomerular Filtration Rate

Elevated AST and ALT activity occurred more frequently in HAART-treated patients on $A Z T+3 T C+E F V$ while abnormal eGFR occurred more frequently in those on AZT+3TC+NVP (Fig 1 ). The prevalence of hepatotoxicity was higher in patients who have been on HAART for over 10 years (34.3\% had elevated AST and $31.4 \%$ had elevated ALT) while renal impairment (elevated creatinine and abnormal eGFR) was higher in those who have been on HAART for 5 to 10 years (Fig 2). 


\section{Discussion:}

The overall prevalence of transaminitis among HIV-infected patients on HAART in our study was $26 \%$ for AST and $20 \%$ for ALT. Although this prevalence was not significantly higher than $15 \%$ and $12 \%$ respectively for HIVnegative control subjects, our finding is similar to that of a study conducted in northwest Ethiopia by Melashu et al., (16) who reported a prevalence of $20.1 \%$ for liver enzyme abnormality in HAART-treated individuals. Megan et al., (17) reported that many studies have shown that HIV infects a wide range of nonhematopoietic cells, including cells of the liver. Destruction of the hepatocytes will be reflected in an upsurge in serum liver enzyme activities. This could possibly explain the elevated liver enzymes observed in the HIV-infected HAART treated subjects in this study.

Our study showed that females in the HAART-treated group had significantly elevated serum AST activity $(81.8 \%)$ compared to HIV negative group (46.7\%) which is consistent with a study conducted in Ghana (18), although that of ALT activity was not significantly related to gender. But serum ALT activity was significantly elevated in age group $20-35$ years (45\%) in the HAART-treated group, which contradicts the report of a study conducted in Yaoundé, Cameroon, where transaminase levels were highest in HAART experienced patients above the age of 50 years (19). Meanwhile among the HIV-negative participants, ALT was significantly elevated in the age group 51-65 years, which may be attributed to the process of aging with gradual alteration of hepatic structure and function as well as various changes in liver cells (20).

In this study, the prevalence of elevated serum creatinine among patients in the HAARTtreated group was $25 \%$ while the prevalence in HIV-negative control was $7 \%(p=0.0010)$. The prevalence of renal impairment in the HAARTtreated group, defined as eGFR $<60 \mathrm{ml} / \mathrm{min} /$ $1.73 \mathrm{~m}^{2}$ using the Cockcroft-Gault formula was $24 \%$, while the prevalence was $14 \%$ in HIVnegative group $(p=0.1048)$. This rate in HAARTtreated patients in our study is higher than the rate of $18.2 \%$ reported in southeast Ethiopia (21), $21 \%$ in northwest Ethiopia (22), $5.5 \%$ in Lesotho (23), 6\% in Uganda (24) and $1.1 \%$ in Tanzania (25). This is inspite of the fact that only subjects with eGFR $<60 \mathrm{ml} / \mathrm{min} / 1.73 \mathrm{~m}^{2}$ were considered to have renal impairment in our study, similar to the study by Yewulsew et al, (21). The variation in the rate compared to other studies may be related to differences in population studied, study design, sample size, and formula/definition used to classify renal impairment (21).

Notably, the prevalence rate of renal impairment among HIV-negative subjects was also high at $14 \%$ though not significantly different from the HAART-treated group $(p=0.1048)$. The statistically similar prevalence rate of renal impairment in HAART-treated and HIV-negative subjects in our study indicate that HAART therapy is effective in preventing HIVrelated renal disease, as this rate was not different from the normal population. The capacity of HAART to reduce viral load, thereby reducing opportunistic infections and improving immunologic response of HIV-infected patients, may account for the non-significant difference in the prevalence of renal impairment in these patients from normal population. In Cameroon, all newly diagnosed HIV patients are immediately placed on HAART as recommended by the World Health Organization, action that we believe has had a great impact in reducing HIV related renal pathologies.

The prevalence of abnormal eGFR $\left(<60 \mathrm{ml} / \mathrm{min} / 1.73 \mathrm{~m}^{2}\right)$ was higher (though not statistically significant, $p=0.5502$ ) in females $(25.6 \%)$ than males $(16.7 \%)$ in the HAARTtreated group, which contradicts the report of Yewulsew et al., (21). This may suggest that the female gender is more predisposed to HAARTinduced renal toxicity. However, the number of females recruited into the HAART-treated arm of our study was higher, with a male to female ratio of $1: 4.5$. Molu et al., (26) reported twice females than males in a study that recruited 712 HIV-infected patients in Cameroon. The disparity in the male to female ratio may be attributed to the increased feminization of the HIV epidemic, with large number of females living with AIDS. Again, most women are screened for HIV during pregnancy as part of the pre-natal examination. Aside this, there is also the possibility of increased compliance to treatment by the female gender.

Characteristically, the prevalence of renal impairment was higher in patients aged 51-65 years in both HAART-treated groups (35.5\%) and HIV-negative subjects (35\%). The two patients with severe renal impairment $(n=1)$ and kidney failure $(n=1)$ in the study, who were actually among the HIV-negative subjects, were older than 50 years of age thus supporting the phenomenon that renal function decreases with age, with the older age being a risk factor in the general population (27).

Our results showed that most of the patients with elevated transaminase levels were on first-line HAART, which is mostly tenofovir- 
based. This was also observed in patients who had renal impairment according to eGFR less than $60 \mathrm{ml} / \mathrm{min} / 1.73 \mathrm{~m}^{2}(24)$. This situation may be due to the direct effect of the tenofovir-based HAART on the liver and kidneys (20), and is contrary to reports of some studies that have documented higher incidence of elevated transaminase activity when protease inhibitors were used $(27,28)$. However, the finding of increase serum ALT and AST activities in HAART treated patients is in agreement with previous studies which reported a characteristic increase in liver transaminases as a result of administration of ART on HIV-infected patients (29).

Patients who have been on treatment duration for longer periods of time had higher prevalence of renal impairment and liver abnormalities in our study. These results are in line with those obtained in a retrospective review of more than 10,000 adults living with AIDS in Boston by Spengler et al., (30), who confirmed that long time antiretroviral therapy is associated with high rate of severe hepatotoxicity regardless of drug class or combination.

One limitation in our study is the unequal ratio of gender and age groups of the HAART-treated group and the HIV-negative control. This was influenced by the study population which was largely made of females and who equally consented to participate in the study. However, to minimize this selection bias, we calculated percentages based on number of participants of either the same gender or the same age group between the cases and controls.

\section{Conclusion:}

In conclusion, we report statistically significant elevation in serum activity of transaminases and serum level of creatinine in HIVinfected patients treated with HAART but no significant difference in the prevalence of renal impairment in these patients compared to HIVnegative population. We recommend that after initiation of HAART, liver enzymes and markers of kidney functions should be used in monitoring patients for signs of hepatic or renal toxicity so that the treatment can be adjusted accordingly.

\section{Acknowledgements:}

The authors are grateful to the management of the Day Care clinic and the Biochemistry Laboratory of the Bamenda Regional Hospital for collaboration during the period of this study. The study participants are acknowledged for accepting to take part in the study.

\section{References:}

1. World Health Organization. HIV/AIDS: Confronting the killer. World Health Report 2003; 41-46.

2. UNAIDS. Report on Global AIDS epidemic. Joint United Nations Programme on HIV/AIDS (UNAIDS) Geneva, 2004.

3. Cihlar, T., Ho, E. S., Lin, D. C., and Mulato, A. S. Human renal organic anion transporter 1 (hOAT1) and its role in the nephrotoxicity of antiviral nucleotide analogs. Nucleos Nucleot Nucl. 2001; 20 (4-7): 641-648.

4. Idigbe, O., Kanki, P., Adewole, T., Onwujekwe, D., Audu, R., and Onyewuche, J. Haematological and biochemical response to treatment of HIV-1 infection with a combination of nevirapine+stavidine+lamivudine in Lagos Nigeria. Turkish Haematol. 2005; 22: 125-131

5. Braitstein, P., Justice, A., Bangsberg, D. R., Yip, B., Alfonso, V., Schechter, M., Hogg, R., and Montaner, J. Hepatitis infection is independently associated with decreased adherence to ART in a population-based HIV cohort. AIDS. 2006; 20 (3): 323-331.

6. Ong, M. M., Latchoumycandane, C., and Boelsterli, U. A. Troglitazone induced hepatic necrosis in an animal model of silent genetic mitochondrial abnormalities. Toxicol Sci. 2007; 97 (1): 205-213.

7. Hanawa, N., Shinohara, M., Saberi, B., Gaarde, W. A., Han, D. and Kaplowitzn, N. Role of JNK translocation to mitochondria leading to inhibition of mitochondria bioenergetics in acetaminophen-induced liver injury. J Biol Chem. 2008; 283 (20): 13565-13577

8. Bonacini, M., and Inductivo-Yu, I. Highly Active Antiretroviral Therapy-Induced Liver Injury. Curr Drug Saf. 2008; 3 (1): 4-13.

9. Gradenswartz, M. H., Lancer, C. W., and Seligbon, G. R. Renal disease in patients with AIDS: A clinicopathologic study. Clin Nephrol. 1984; 21: 194-204.

10. Pardo, V., Aldana, M., and Colton, R. M. Glomerular lesions in the Acquired Immuno-deficiency Syndrome. Ann Intern Med. 1984; 101: 429-434.

11. Rosenberg, A. Z., Naicker, S., Winkler, A., and Kopp, J. B. HIV AN, Epidemiology, pathology, mechanisms and treatment. Nat Rev Nephrol. 2015; 11: 150-160

12. Cochran, W. G. Sampling techniques (3rd ed.). 1977, New York: John Wiley \& Sons.

13. Wondifraw, B. H., Tegene, B., Gebremichael, M., Birhane, G., Kedir, W., and Biadgo, B. Assessment of the effect of antiretroviral therapy on renal and liver functions among HIV-infected patients: a retrospective study. HIV AIDS (Auckl). 2016; 9: 1-7.

14. Division of AIDS (DAIDS), National Institute of Allergy and Infectious Diseases National Institutes of Health US Department of Health and Human Services. Table for Grading the Severity of Adult and Pediatric Adverse Events. $\quad 2017$. https://rsc.niaid.nih.gov/sites/default/files/daidsgrading correctedv21.pdf

15. Cockcroft, D. W., and Gault, M. H. Prediction of creatinine clearance from serum creatinine. Nephron.1976; 16: 3141.

16. Melashu, B. S., Ketema, T., Tulu, A., and Asratie, W. Liver enzymes abnormalities among HAART experienced and HAART naïve HIV-infected patients at Debre Tabor hospital, Northwest Ethiopia. AIDS Research and Treatment. 2016; 7:

17. Megan, C., David, I., and Sharon, R. L. Human Immunodeficiency Virus and the liver. World J Hepatol. 2012; 4 (3): 91-98.

18. Osakunor, D. N. M., Obirikorang, C., Fianu, V., Asare, I., and Dakorah, M. Hepatic Enzyme Alterations in HIV Patients on Antiretroviral Therapy: A Case-Control Study in a Hospital Setting in Ghana. PLoS One 2015; 10 (8).

19. Lucien, K. F. H., Clement, A. N. J., Fon, N. P., Weledji, P., and Ndikvu C. P. The Effects of Antiretroviral 
Treatment on Liver Function Enzymes among HIVInfected Outpatients Attending the Central Hospital of Yaoundé, Cameroon. Afr J Clin Exper Microbiol. 2010; 11(3): 174-178.

20. Le Couteur, D. G., Warren, A., Cogger, V. C., Smedsrød, B., Sørensen, K. K., De Cabo, R., Fraser, R., and McCuskey, R. S. Old age and the hepatic sinusoid. Anat Rec (Hoboken) 2008; 291: 672-683.

21. Yewulsew, M., Yilma, D., Zeleke, M., Tesfaye, K., and Lealem, G. Renal function impairment and its associated factors among HAART naïve and experienced Adult HIV positive individuals in South East Ethiopia: A Comparative Cross-Sectional Study. PLoS One. 2016; 11 (8):

22. Kahsu, G., Birhan, W., Addis, Z., Dagnew, M., and Abera, B. Renal function impairment and associated risk factors among HIV positive Individuals at Felege Hiwot Referral Hospital. Northwest Ethiopia. J Interdiscipl Histopathol. 2013; 1 (5).

23. Bygrave, H., Kranzer, K., Hilderbrand, K., Jouquet, G., Goemaere, E., Vlahakis, N., Triviño, L., Makakole, L., and Ford, N. Renal safety of a Tenofovir-Containing First Line Regimen: Experience from an antiretroviral cohort in rural Lesotho. PLoS One. 2011; 6 (3).

24. Peters, P. J., Moore, D. M., Mermin, J., Brooks, J. T., Downing, R., Were, W., Kigozi, A., Buchaccz, K., and
Weidle, P. J. Antiretroviral therapy improves renal function among HIV- positive Ugandans. Renal International. 2008; 74: 925-929.

25. Mpondo, B. C., Kalluvy, S. E., Peck, R. N., Kabangila, R., Kidenya, B. R., Ephraim, L., Fitzgerald, D. W., and Downs, J. A. Impact of antiretroviral therapy on renal function among HIV- positive Tanzanian adults. PLoS One. 2014; 9 (2).

26. Molu, J. P., Essome, M. C. N., Monamele, C. G., Njouom, $R$. Sero-prevalence of $\mathrm{HBSAg}$ in naive HIV-infected patients in a rural locality of Cameroon. BMC Res Notes. 2018; 11 (1): 39.

27. Sulkowski, M., Thomas, D. L., Chaisson, R, E., and Moore, R. D. Hepatotoxicity associated with antiretroviral therapy in adults infected with HIV and the role of Hepatitis B or C infection, JAMA, 2000; 284: 74-80.

28. Hoffmann, C. J., and Thio, C. L. Clinical implications of HIV and hepatitis B co-infection in Asia and Africa. Lancet Infect Dis. 2007; 7: 402-409

29. Helen, K., and Rainer, W. Influence of antiretroviral therapy on liver disease. Curr Opin HIV AIDS. 2011; 6 (4): 272-277.

30. Spengler, U., Lichterfeld, M., and Rockstroh, J. K. Antiretroviral drug toxicity-Therapy. Reuters Health 2002 